\title{
IMPLEMENTASI PEMBELAJARAN AKTIF, KREATIF, EFEKTIF DAN MENYENANGKAN DI MI MITRA PGMI STAIN PONOROGO
}

\author{
Athok Fu'adi \\ Dosen Tetap Program Studi S1 PGMI STAIN Ponorogo
}

\begin{abstract}
This study aimed to describe the implementation of active learning, creative, effective and fun at MI Partners PGMI STAIN Ponorogo which include: 1) preparation PAKEM learning, 2) implementation PAKEM learning, 3) PAKEM learning assessment, and 4) factors inhibiting and supporting learning PAKEM. This research is a qualitative research subject was a teacher at MI Partners Ma'arif Polorejo and Setono. Research instrument is the researcher himself. Data were collected through interviews, observation, documentation. The validity of data obtained by performing triangulation and constant observation. Data analysis was performed since the data were collected using an interactive model that consists of three stages, namely data reduction, data entry, and conclusion. The results showed that the preparation of learning PAKEM, found some teachers had not made in accordance with the characteristics of RPP PAKEM, this is because the model was still hung up on previous learning. Implementation of the learning PAKEM already running but not fully performed by all classes, only a few classes. Implementation of assessment, and classroom-based assessment using 3 domains, cognitive, affective and psychomotor, but to apply all that trouble. Barriers and support in learning PAKEM, obstacle lies in the teachers themselves and infrastructure facilities in the form of instructional media, while support from all stakeholders.

Keywords: active, creative, and effective learning (PAKEM), Madrasah
\end{abstract}

\section{A. Pendahuluan}

\section{Latar Belakang}

Era globalisasi menuntut perubahan di segala bidang dengan cepat. Berbagai rumpun keilmuan mengalami kemajuan dengan pesat, termasuk 
Athok Fu'adi - Implementasi Pembelajaran Aktif, Kreatif, Efektif

dalam bidang pendidikan. Peningkatan mutu pendidikan di Indonesia telah menjadi kebutuhan yang mendesak saat ini. Persaingan lulusan pendidikan semakin ketat, terutama dalam segi kualitas. Tuntutan masyarakat bahwa mutu pendidikan bisa meningkatkan kesejahteraan hidup masyarakat, perlu dijawab dengan berbagai inovasi dalam dunia pendidikan.

Peningkatan kualitas pendidikan merupakan tujuan bersama yang harus dilakukan demi meningkatkan mutu pendidikan di Indonesia. Pihak pemerintah telah berusaha untuk merumuskan berbagai macam strategi untuk meningkatkan kualitas pendidikan dan melakukan inovasi pendidikan sebagai bagian dari reformasi pendidikan. Undang-Undang No 20 tahun 2003 tentang sistem pendidikan nasional, yang berisi penjelasan tentang tujuan pendidikan serta upaya-upaya peningkatan pendidikan, merupakan salah satu produk reformasi pendidikan.

Fungsi dan tujuan pendidikan nasional seperti yang tercantum pada Undang-undang sistem pendidikan pada Bab II pasal 3 tahun 2003, yaitu:

Mengembangkan kemampuan dan membentuk watak serta peradaban bangsa yang bermartabat dalam rangka mencerdaskan kehidupan bangsa, bertujuan untuk berkembangnya potensi peserta didik agar menjadi manusia yang beriman dan bertakwa kepada Tuhan Yang Maha Esa, berakhlak mulia, sehat, berilmu, cakap, kreatif, mandiri, dan menjadi warga negara yang demokratis serta bertanggungjawab.

Perwujudan masyarakat Indonesia yang berkualitas menjadi tanggung jawab dunia pendidikan, terutama dalam mempersiapkan peserta didik menjadi subjek yang makin tangguh, kreatif, mandiri dan profesional menurut bidang keilmuannya masing-masing. Hal ini merupakan sesuatu yang perlu diperhatikan demi mengantisipasi era kesejagatan yang mulai kita rasakan.

Menurut PP No 19 tahun 2005 tentang Standar Nasional Pendidikan, pada bab IV tentang standar proses, diungkapkan bahwa proses pembelajaran pada satuan pendidikan diselenggarakan secara interaktif, inspiratif, menyenangkan, menantang, memotivasi peserta didik untuk berpartisipasi aktif, serta memberikan ruang yang cukup bagi prakarsa, kreativitas, dan kemandirian sesuai dengan bakat, minat, dan perkembangan fisik serta psikologis peserta didik. 
Athok Fu'adi - Implementasi Pembelajaran Aktif, Kreatif, Efektif

Untuk menghasilkan lulusan murid MI yang berkualitas, seorang guru MI diharuskan memiliki kemampuan melaksanakan pembelajaran yang berkualitas dan bervariasi. Kegiatan pembelajaran yang berkualitas akan dapat tercapai apabila kegiatan pembelajaran membuat siswa MI menjadi aktif, kreatif, senang belajar serta kegiatan pembelajaran yang efektif. Guru MI akan mampu menyelenggarakan pembelajaran yang berkualitas apabila guru MI tersebut menguasai komponen-komponen penyelenggaraan PAKEM dengan baik.

STAIN Ponorogo mempunyai MI Mitra, jumlah MI Mitra adalah 11 madrasah, yang telah menyelenggarakan proses pembelajaran aktif, kreatif, dan menyenangkan masih 5 MI Mitra. Untuk penelitian ini hanya mengambil MI Setono dan MI Polorejo dikarenakan kedua MI ini sudah dapat diteliti pembelajaran PAKEM-nya.

\section{Rumusan Masalah}

Berdasarkan latar belakang tersebut maka dapat dirumuskan masalah sebagai berikut:

1. Bagaimanakah persiapan guru MI Mitra PGMI STAIN Ponorogo dalam pembelajaran PAKEM?

2. Bagaimana pelaksanaan pembelajaran PAKEM di MI Mitra PGMI STAIN Ponorogo?

3. Bagaimanakah penerapan sistem penilaian dalam pembelajaran PAKEM di MI Mitra PGMI STAIN Ponorogo?

4. Faktor-faktor apa sajakah yang mendukung dan menghambat pembelajaran PAKEM di MI Mitra PGMI STAIN Ponorogo?

\section{Metode Penelitian}

1. Jenis atau Desain Penelitian

Penelitian ini merupakan penelitian kualitatif, yaitu memaparkan semua fenomena dan kejadian yang terjadi dalam setting penelitian. Fenomena yang terjadi meliputi persiapan pembelajaran PAKEM, proses pembelajaran PAKEM di kelas, serta penilaian PAKEM. Sebagai pendukung informasi dalam penelitian ini maka fenomena lingkungan madrasah, aktivitas siswa dan juga pemanfaatan sarana pembelajaran, dan proses pengembangan kompetensi guru dilaporkan. Dalam penelitian ini, pengumpulan data secara deskriptif yang dituangkan dalam bentuk 
laporan, tidak mengutamakan angka-angka walaupun tidak menolak data kuantitatif demi memperkaya hasil penelitian.

\section{Teknik Pengumpulan Data}

Teknik pengumpulan data dalam penelitian ini adalah angket, observasi, wawancara dan dokumentasi.

a. Observasi, digunakan untuk cross cek data mengenai pelaksanaan PAKEM.

b. Wawancara, digunakan untuk mendapatkan data tentang proses pembelajaran aktif, kreatif, efektif dan menyenangkan (PAKEM), dalam hal ini kesiapan kepala sekolah dan guru serta faktor-faktor pendukung dan kendala yang ditemui dilapangan. Subjek dalam penelitian ini adalah guru sebagai tenaga pengajar dan siswa sebagai peserta didik. Dalam penelitian kualitatif metode yang digunakan dalam pengumpulan data adalah wawancara atau interview. Pengumpulan data dengan wawancara ditujukan pada informan terpilih yang pertimbangannya adalah relevansi dengan tujuan penelitian. Wawancara dilakukan untuk melengkapi data observasi dan sebagai bentuk triangulasi data. Wawancara dilakukan dengan pertanyaan terstruktur dan bebas.

c. Dokumentasi, digunakan untuk mendapatkan data mengenai kesiapan sarana dan prasarana, perencanaan kegiatan, siswa, jumlah guru, dan kondisi sekolah dan sebagainya yang berkenaan dengan penelitian ini.

\section{Teknik Analisis Data}

Teknik analisis data kualitatif yang digunakan adalah model interaktif sebagai berikut (Miles, M.B.\& Huberman, A.M. 1992:16-19):

Reduksi data, digunakan untuk memilih dan menyederhanakan datadata kasar yang muncul dari catatan-catatan tertulis dilapangan. Penyajian data digunakan untuk menyajikan sekumpulan data/informasi dengan sistematis dan tersusun agar mudah difahami secara utuh dan integral. Verifikasi (menarik kesimpulan) didasarkan pada hasil pembahasan dan hasil analisis dengan memperhatikan problem penelitian sehingga dapat memberikan arti penting temuan penelitian, dengan maksud mencari makna. tentang data yang dikumpulkan. Setelah data di lapangan terkumpul, peneliti langsung melakukan analisis untuk menghindari bertumpuknya data yang mengakibatkan tereduksinya validitas dan 
Athok Fu'adi - Implementasi Pembelajaran Aktif, Kreatif, Efektif

kredibilitas data. Jenis analisis yang dilakukan adalah analisis interaktif, yang terdiri dari tiga alur kegiatan yang berjalan secara simultan, yaitu: reduksi data, penyajian data dan penarikan kesimpulan.

\section{B. Kajian Teori (Pembelajaran Aktif, Kreatif, Efektif, dan Menyenangkan)}

1. Pembelajaran

Undang-Undang No. 20 tahun 2003 tentang Sisdiknas, bahwa pembelajaran adalah proses interaksi peserta didik dengan pendidik dan sumber belajar pada suatu lingkungan belajar. Sedangkan "Pembelajaran merupakan upaya pendidik untuk membantu peserta didik untuk melakukan kegiatan belajar." (Nana Sudjana, 1989:18). Hal ini didukung dengan pendapat "Instruction is human undertaking whose purpose is to help people learn", yang mempunyai arti bahwa pembelajaran merupakan upaya orang yang tujuannya membantu orang belajar. Selanjutnya pada buku yang sama dijelaskan bahwa: "Instuction is the mean employed by teacher,designers of materials, curriculum specialist, and others whose purpose it is to develop an organized plan to promote learning" (Bower, G.H. \& Hilgard, E.R, 1975:78). Hal ini berarti kegiatan pembelajaran mengandung makna sebagai cara yang dipakai oleh pengajar, perancang media, ahli kurikulum yang ditujukan untuk mengembangkan rencana yang terorganisasi guna keperluan belajar.

\section{Langkah-langkah pembelajaran}

Pembelajaran dapat berlangsung secara efektif dan efisien bila direncanakan. Langkah-langkah dalam pembelajaran meliputi: perencanaan, pelaksanaan, dan evaluasi.

a. Perencanaan pembelajaran

“Keberhasilan pelaksanaan pembelajaran terpadu bergantung pada kesesuaian rencana yang dibuat dengan kondisi dan potensi peserta didik yang meliputi: bakat, minat, kebutuhan, dan kemampuan". Untuk menyusun perencanaan pembelajaran perlu dilakukan langkah-langkah pembelajaran (Depdiknas, 2008).

\section{b. Pelaksanaan pembelajaran}

Pelaksanaan pembelajaran yang efektif ialah dengan banyak mengikutsertakan siswa dalam proses pembelajaran dengan cara siswa diberi kesempatan untuk berintregrasi dengan kehidupan nyata 
Athok Fu'adi - Implementasi Pembelajaran Aktif, Kreatif, Efektif

berdasarkan pengetahuan yang dimilikinya, diharapkan siswa dapat mengembangkan daya pikir dan kreatifitasnya. Oleh karena itu perencanaan pembelajaran yang baik akan mendukung suksesnya pelaksanaan pembelajaran.

\section{c. Penilaian}

Penilaian mencakup penilaian terhadap proses dan penilaian terhadap hasil belajar peserta didik. Penilaian proses belajar adalah upaya pemberian nilai terhadap kegiatan pembelajaran yang dilakukan oleh guru dan peserta didik. Penilaian hasil belajar adalah proses pemberian nilai terhadap hasil-hasil belajar yang dicapai dengan menggunakan kriteriakriteria tertentu. Kedua penilaian tersebut saling berkaitan satu dengan yang lainnya karena hasil belajar merupakan akibat dari suatu proses belajar.

2. Model Pembelajaran Aktif, Kreatif, Efektif dan Menyenangkan (PAKEM)

Model pembelajaran PAKEM (pembelajaran aktif, kreatif, efektif dan menyenangkan) merupakan model pembelajaran yang ada dalam KTSP. Secara umum tujuan penerapan PAKEM adalah agar proses pembelajaran yang dilaksanakan dikelas dapat merangsang aktifitas dan kreatifitas belajar peserta didik serta dilaksanakan dengan efektif dan menyenangkan. Model ini merupakan salah satu alternatif solusi untuk menciptakan lulusan yang berkualitas, kompetitif dan unggul.

Dalam melaksanakan pembelajaran aktif, kreatif, efektif, dan menyenangkan ini, tentunya ada beberapa hal yang harus diperhatikan agar dalam aplikasi pembelajarannya benar-benar tercipta suasana belajar yang efektif. Hal tersebut adalah:

1. Memahami sifat yang dimiliki siswa.

2. Mengenal siswa secara perorangan.

3. Memanfaatkan perilaku siswa dalam pengorganisasian pembelajaran.

4. Mengembangkan kemampuan berpikir kritis, kreatif, dan kemampuan memecahkan masalah.

5. Memanfaatkan lingkungan sebagai sumber belajar.

6. Memberikan umpan balik yang baik untuk meningkatkan kegiatan pembelajaran.

7. Membedakan antara aktif dan aktif mental. Banyak guru yang sudah merasa puas bila menyaksikan para siswanya kelihatan sibuk bekerja dan bergerak.

24 Madrasah, Vol. 3 No. 1 Juli-Desember 2011 
Dijelaskan PAKEM dapat digambarkan sebagai berikut (Modul Workshop LAPIS-PGMI, 2008:12):

1. Siswa terlibat dalam berbagai kegiatan yang mengembangkan pemahaman dan kemampuan mereka dengan penekanan pada mata pelajaran melalui perbuatan.

2. Guru menggunakan berbagai alat bantu dan berbagai cara dalam membangkitkan semangat, termasuk menggunakan lingkungan sebagai sumber belajar untuk menjadikan pembelajaran menarik, menyenangkan, dan cocok bagi peserta didik.

3. Guru menerapkan sistem pembelajaran yang lebih kooperatif dan interaktif, termasuk cara belajar kelompok.

4. Guru mendorong peserta didik untuk menemukan caranya sendiri dalam pemecahan suatu masalah, untuk mengungkapkan gagasannya, dan melibatkan peserta didik dalam menciptakan lingkungan belajar.

a. Pembelajaran Aktif (active learning)

Karakteristik Pembelajaran Aktif, diantaranya adalah:

1) Pembelajaran tidak ditekankan pada penyampaian informasi oleh pengajar melainkan pada eksplorasi informasi dan pembangunan konsep oleh peserta didik.

2) Atmosfer pembelajaran mendukung/kondusif proses pembelajaran.

3) Siswa tidak hanya mendengarkan ceramah secara pasif melainkan mengerjakan berbagai hal (membaca, melihat, mendengar, melakukan eksperimen dan berdiskusi) yang berkaitan dengan materi pembelajaran.

4) Siswa dilibatkan dalam kegiatan-kegiatan kooperatif yang membutuhkan tanggung jawab individual sekaligus ketergantungan positif antar anggota kelompok.

5) Siswa dirangsang untuk menggunakan kemampuan berfikir kritis, analisa dan evaluasi.

6) Siswa terlibat dalam pemanfaatan berbagai sumber belajar baik di dalam maupun di luar kelas.

7) Guru mendapatkan umpan balik yang lebih cepat tentang proses dan hasil pembelajaran.

b. Pembelajaran Kreatif (creative learning) 
Pembelajaran kreatif merupakan proses pembelajaran yang mengharuskan guru untuk dapat memotivasi dan memunculkan kreatifitas peserta didik selama proses pembelajaran berlangsung dengan menggunakan beberapa metode dan strategi yang variatif misalnya kerja kelompok, pemecahan masalah dan sebagainya.

c. Pembelajaran efektif (effective learning)

Beberapa prosedur yang dapat dilakukan dalam melakukan proses pembelajaran efektif antara lain:

1) Melakukan apersepsi (pemanasan)

2) Eksplorasi

3) Konsolidasi pembelajaran

4) Penilaian

Untuk menciptakan proses pembelajaran yang efektif, guru harus memperhatikan ha-hal sebagai berikut:

1) Pengelolaan tempat belajar.

2) Pengelolaan peserta didik

3) Pengelolaan kegiatan pembelajaran

Ada tiga hal strategis yang harus dikuasai guru dalam pengelolaan kegiatan pembelajaran:

a) Penyediaan pertanyaan yang mendorong berpikir dan berproduksi

b) Penyediaan umpan balik yang bermakna

c) Penyediaan penilaian yang memberi peluang semua peserta didik mampu melakukan unjuk perbuatan.

4) Pengelolaan isi atau materi pembelajaran

5) Pengelolaan sumber belajar

d. Pembelajaran yang menyenangkan

Sehubungan dengan ciri menyenangkan dalam PAKEM, Rose and Nocholl (2003) mengatakan bahwa pembelajaran yang menyenangkan mempunyai ciri-ciri sebagai berikut :

1) Menciptakan lingkungan tanpa stress (relaks), lingkungan yang aman untuk melakukan kesalahan, namum harapan untuk sukses tetap tinggi.

2) Menjamin bahwa bahan ajar itu relevan. Anda ingin belajar ketika Anda melihat manfaat dan pentingnya bahan ajar. Demikian Rose dan Nicholl. 
Athok Fu'adi - Implementasi Pembelajaran Aktif, Kreatif, Efektif

3) Menjamin bahwa belajar secara emosional adalah positif, yang pada umumnya hal itu terjadi ketika belajar dilakukan bersama orang lain, ketika ada humor dan dorongan semangat,waktu istirahat dan jeda teratur serta dukungan antusias.

4) Melibatkan secara sadar semua indera dan juga pikiran otak kiri dan otak kanan.

5) Menantang peserta didik untuk dapat berpikir jauh ke depan dan mengekspresikan apa yang sedang dipelajari dengan sebanyak mungkin kecerdasan yang relevan untuk memahami bahan ajar.

6) Pembelajaran ini merupakan pembelajaran yang didalamnya terdapat interaksi yang kuat antara pendidik dan peserta didik dengan tanpa ada perasaan tertekan. Dengan kata lain pembelajaran menyenagkan adalah adanya pola hubungan yang baik antara guru dan peserta didik dalam proses pembelajaran. Guru memposisikan diri sebagai mitra belajar peserta didik di kelas, sehingga tidak ada beban bagi peserta didik dalam melakukan proses pembelajaran.

\section{Hasil Penelitian Pembelajaran PAKEM}

Laporan hasil penelitian tentang implementasi pembelajaran PAKEM di MI Mitra STAIN Ponorogo dipaparkan sesuai dengan observasi peneliti sekaligus hasil wawancara kepada informan yang terkait dengan persiapan pembelajaran PAKEM, proses pembelajaran PAKEM yang terdiri dari mengelola kelas, mengelola siswa, pojok baca, pajangan dan proses penilaian yang terdiri dari penilaian kognitif, afektif dan psikomotor.

Untuk lebih memudahkan dalam pemahaman, laporan hasil penelitian ini dibagi menjadi beberapa bagian laporan. Persiapan pembelajaran, Proses pembelajaran yang meliputi mengelola kelas, mengelola siswa, mengelola kegiatan pembelajaran, metode pembelajaran, pojok baca, pajangan dan penilaian pembelajaran PAKEM yang meliputi penilaian kognitif, afektif dan psikomotor.

\section{Persiapan Pembelajaran PAKEM}

Sebelum pembelajaran di kelas, guru membuat perencanaanperencanaan yang dilakukan dalam satu semester, sebagimana di ungkapkan oleh Guru MI Setono (Bu F). Sebelum pembelajaran berlangsung guru membuat RPP, Prota, Promes dan itu semua dibuat oleh 
Athok Fu'adi - Implementasi Pembelajaran Aktif, Kreatif, Efektif

guru dan dijilid selanjutnya di tanda tangani kepala sekolah. ${ }^{1}$ Demikian juga oleh MI Polorejo bahwa setiap guru harus membuat persiapanpersiapan yang dibuat oleh guru sebelum mengajar. ${ }^{2}$ Hal ini didukung oleh data observasi di kedua lembaga ${ }^{3}$.

\section{a. Guru Membuat Program Semester}

Program semester dan program tahunan harus dibuat oleh guru sebelum melaksanakan pembelajaran, hal ini didukung oleh data hasil wawancara ${ }^{4}$ dan hasil observasi ${ }^{5}$ yang memperlihatkan bahwa setiap guru harus mempunyai program semester dan tahunan.

\section{b. Guru Menyusun Silabus}

Untuk silabus guru sudah ada dari pusat hal ini dapat dilihat hasil wawancara $^{6}$ dan data observasi ${ }^{7}$ bahwa setiap guru sudah mempunyai silabus untuk persiapannya dalam pembelajaran.

Untuk silabus ini sudah ada panduannya dari pusat sedangkan guru hanya mengembangkan indikator yang disesuaikan oleh lembaga ${ }^{8}$.

\section{c. Guru Menyusun RPP}

Penyusunan RPP guru tidak semuanya siap, hal ini dapat dilihat hasil dari data wawancara ${ }^{9}$ dan observasi ${ }^{10}$ untuk guru kelas awal belum semua, karena merasa kesulitan dengan RPP tematik, baik itu di lembaga MI Polorejo maupun MI Setono sedangkan yang kelas atas semua guru sudah ada silabusnya karena sejak tahun kemarin sudah disiapkan sehingga ketika ada pengambilan data mereka memperlihatkan RPP yang lama, sedangkan untuk RPP yang baru masih membuat pertemuan ${ }^{11}$.

Persiapan pembelajaran yang dilakukan guru terdiri dari membuat silabus dan mengembangkan serta merancang tentang pelaksanaannya

\footnotetext{
${ }^{1}$ Wawancara, 01/1-W/F-1/13-IV/2009

${ }^{2}$ Wawancara, 02/1-W/F-1/18-IV/2009

${ }^{3}$ Observasi, 01/O/F-2/20-IV/2009

${ }^{4}$ Wawancara, 03/1-W/F-1/22-IV/2009

${ }^{5}$ Observasi, 02/O/F-2/25-IV/2009

${ }^{6}$ Wawancara, 03/1-W/F-1/27-IV/2009

${ }^{7}$ Observasi, 03/O/F-2/29-IV/2009

${ }^{8}$ Wawancara, 04/1-W/F-1/04-V/2009

${ }^{9}$ Wawancara, 05/1-W/F-1/06-V/2009

${ }^{10}$ Observasi, 04/O/F-2/9-V/2009

${ }^{11}$ Observasi, 05/O/F-2/11-V/2009
}

28 Madrasah, Vol. 3 No. 1 Juli-Desember 2011 
Athok Fu'adi - Implementasi Pembelajaran Aktif, Kreatif, Efektif

pada dasarnya melalui perencanaan dalam pembelajaran, terdiri enam kolom yang harus diisi oleh guru, yaitu pertama tentang identitas mata pelajaran yang di dalamnya menyangkut satuan pendidikan, mata pelajaran, kelas/semester, materi pokok, dan waktu. Sedangkan yang kedua standar berkenaan dengan kompetensi/standar kompetensi dasar dan indikator. Data disalah satu dokumen guru-guru MI menerangkan bahwa indikator yang dibuat harus dikembangkan sesuai dengan karakteristik siswa. Ketiga adalah materi pelajaran. Keempat adalah strategi pembelajaran yang di dalamnya terdapat pendahuluan kegiatan inti dan juga penutup. Keenam adalah penilaian tindak lanjut.

2. Pelaksanaan Pembelajaran PAKEM

a. Guru Menggunakan Multimetode

Hasil Observasi guru MI12 dan hasil wawancara13 beberapa guru sudah menggunakan multimetode khususnya yang kelas bawah, sedangkan untuk kelas atas masih beberapa guru saja. Metode yang selalu digunakan guru dalam pembelajaran PAKEM adalah:

1) Metode Ceramah

Metode ceramah dilakukan dalam menyampaikan pembelajaran PAKEM. Guru masih menyertai ceramahnya dengan pertanyaanpertanyaan dan stimulus-stimulus yang dikaitkan dengan sekitar masalah siswa, sehingga materi pelajaran dapat disampaikan dengan cara sederhana tetapi mengena. Berdasarkan pada saat metode ini digunakan, siswa memberikan perhatian dan juga respon dengan bertanya ${ }^{14}$.

2) Metode Penugasan

Metode penugasan sering digunakan sebagai salah satu cara untuk menilai siswa dalam pendalaman materi, bisa juga digunakan untuk remedial. Dalam kegiatan pembelajaran PAKEM ,Penugasan dilakukan dengan tujuan agar siswa mampu menguasai kompetensi dalam bidangnya. Penugasan dilakukan baik secara individu maupun kelompok. Untuk tugas individu, tugas berupa pekerjaan rumah, sedangkan tugas

${ }^{12}$ Observasi, 05/O/F-2/11-V/2009

${ }^{13}$ Observasi, 06/O/F-2/16-V/2009

${ }^{14}$ Wawancara, 06/1-W/F-1/18-V/2009

29 Madrasah, Vol. 3 No. 1 Juli-Desember 2011 
Athok Fu'adi - Implementasi Pembelajaran Aktif, Kreatif, Efektif

kelompok dikerjakan di sekolah ${ }^{15}$. Penugasan dilakukan dengan tugastugas sederhana.

3) Metode Diskusi

Metode diskusi digunakan sebagai suatu proses penyampaian materi pembelajaran dengan dialog bersama dalam kelas untuk mencari jalan pemecahan dan menyerap serta menganalisa materi pembelajaran tertentu. Dalam metode diskusi penekanan aktivitas belajar terletak pada siswa. Guru berperan sebagai fasilitator dan pengatur lalu lintas informasi antar siswa, sebagai pengatur informasi dan stimulator dalam diskusi, guru harus bisa mengarahkan agar apa yang didiskusikan dapat mengandung kompetensi yang harus dimiliki oleh siswa. Sebelum diskusi guru memberikan materi terlebih dulu, kemudian guru membagi siswa menjadi empat kelompok dengan empat orang anggota sesuai dengan tempat duduknya. Hasil diskusi kelompok biasanya dipresentasikan di depan kelas. ${ }^{16}$ Dalam metode diskusi ini terlihat peserta didik sangat senang. Metode diskusi sangat mengembangkan pengetahuan siswa dengan cara siswa menambah referensi buku yang belum diketahui dalam tema diskusi. Presentasi di depan kelas mengembangkan bakat serta melatih siswa untuk bisa berbicara di depan umum ${ }^{17}$.

4) Metode Permainan

Metode permainan ini digunakan sebagai bentuk variasi yang selama ini digunakan yaitu ceramah. Metode permainan ini sangat disukai oleh siswa karena tidak membosankan bagi siswa, permainan ini juga melatih siswa untuk berpikir cepat karena harus saling mendahului jawaban dari teman-teman lain di kelas. Metode permainan diperlukan ketika variasi metode pembelajaran.

5) Metode Cerita

Metode cerita masih digunakan dalam pembelajaran PAKEM. Metode ini digunakan berkaitan untuk penilaian sikap. Metode cerita ini sangat efektif dilakukan jika siswa juga dilibatkan, bukan hanya guru saja, sehingga dalam pembelajaran dengan metode cerita ini, siswa bisa aktif untuk berfikir bersama untuk menyampaikan pendapatnya.

${ }^{15}$ Observasi, 07/O/F-2/25-V/2009

${ }^{16}$ Observasi, 08/O/F-2/28-V/2009

${ }^{17}$ Observasi, 09/O/F-2/30-V/2009

30 Madrasah, Vol. 3 No. 1 Juli-Desember 2011 


\section{b. Guru Menggunakan Media Pembelajaran}

Media pembelajaran yang ada di sekolah ini dirasakan sudah cukup memadai untuk sebuah proses pembelajaran, tinggal bagaimana cara memanfaatkannya agar bisa mendapatkan hasil belajar yang maksimal ${ }^{18}$. Berbagai media digunakan dalam pembelajaran PAKEM, media yang dapat digunakan merupakan media yang ada di sekitar kita, dengan menggunakan alat-alat yang ada disekitar kita maka akan lebih murah. Untuk sekarang ini media pembelajaran yang ada di MI Ma'arif Polorejo dan MI Ma'arif Setono ada komputer serta alat peraga. Pemanfaatan media pembelajaran yang tersedia, seharusnya dapat mempercepat proses pembelajaran.

\section{c. Guru Mengelola Kelas dengan Dinamis}

Ruangan kelas, posisi kursi dan meja serta meja guru perlu ditata untuk menunjang kegiatan belajar mengajar yang mengaktifkan siswa. Dilihat dari beberapa observasi ${ }^{19}$, lingkungan kelas kurang begitu mendukung sebab banyaknya meja kursi melebihi kapasitas ruangan. Ruangan kelas kelihatan penuh dengan kursi sehingga ruang gerak siswa dan guru terbatasi. Tetapi kondisi fisik seperti itu tidak mempengaruhi proses pembelajaran di kelas karena siswa masih bisa menjangkau alat-alat pembelajaran dengan lewat jalan yang ditata diantara kursi dan meja.

Model pengelolaan kelas yang baik mendorong terciptanya suasana yang kondusif dan memberikan motivasi untuk belajar, sehingga siswa tidak merasa lelah dan jenuh. Pengelolaan kelas diseuaikan dengan membentuk formasi kursi "U" dan berubah-rubah. Sehingga proses pembelajaran menjadi aktif, karena dalam mengajar guru telah menerapkan pembelajaran aktif ${ }^{20}$.

Pengkondisian kelas masing-masing guru berbeda, tergantung bagaimana guru berinteraksi di dalam kelas. Interaksi yang baik dapat menunjang keberhasilan siswa dalam menguasai materi. Pengelolaan interaksi yang dimaksud adalah bagaimana guru mengatur situasi dan kondisi awal, serta bagaimana mengendalikan kelas agar pembelajaran berlangsung efektif.

\footnotetext{
${ }^{18}$ Observasi, 10/O/F-2/1-VI/2009

${ }^{19}$ Observasi, 11/O/F-2/6-VI/2009

${ }^{20}$ Observasi, 12/O/F-2/8-VI/2009
}

31 Madrasah, Vol. 3 No. 1 Juli-Desember 2011 
Dari observasi di dalam kelas dapat diketahui bahwa pembelajaran mata pelajaran ini tergantung pada persiapan guru dalam pembelajaran selain itu penggunakan berbagai macam strategi dan metode pembelajaran dalam mengajar, sebagian guru berhasil mendorong terwujudnya situasi belajar yang lebih kondusif, menarik, dan memotivasi belajar siswa.

\section{d. Guru Menampilkan Pajangan Karya Siswa}

Salah satu ciri pembelajaran PAKEM adalah adanya pajangan, untuk pajangan dilihat dari observasi di kedua lembaga sudah mulai di pajang. ${ }^{21}$ Hal ini akan memberikan suasana lain di kelas tersebut, dengan banyaknya pajangan maka akan semakin menambah siswa membuat tugas dengan sebaik-baiknya. Pajangan yang di taruh di kelas berbagai macam bentuk dan macamnya, hal ini dapat dilihat di setiap kelas.

e. Setiap Kelas Ada pojok Baca

Untuk pojok baca kedua lembaga belum semua kelas, hal ini hanya ada di kelas VI untuk MI Setono22, sedangkan untuk MI Polorejo hanya masih di kelas I, sehingga fungsi dari pojok baca masih sedikit, belum maksimal.

\section{f. Setiap Kelas ada Alat Peraga}

Setiap lembaga tidak sama dalam mempersiapkan alat peraga dikelas, karena berbagai alasan maka alat peraga yang seharusnya di taruh didalam kelas, ditaruh didalam suatu ruangan tersendiri sehingga jika akan melakukan kegiatan peragaan maka akan memakan waktu. Hal ini dapat dilihat observasi ${ }^{23}$ dan hasil wawancara dengan kepala sekolah ${ }^{24}$.

\section{Sistem Penilaian Pembelajaran PAKEM}

Penilaian merupakan suatu proses pengumpulan, pelaporan dan penggunaan informasi tentang hasil belajar siswa yang diperoleh melalui pengukuran untuk menganalisa atau menjelaskan unjuk kerja atau prestasi siswa dalam mengerjakan tugas-tugas terkait.25 Penilaian dalam pembelajaran PAKEM adalah Penilaian Berbasis Kelas (PBK). Penilaian

${ }^{21}$ Observasi, 13/0/F-2/13-VI/2009

${ }^{22}$ Observasi, 14/O/F-2/22-VI/2009

${ }^{23}$ Observasi, 15/O/F-2/27-VI/2009

${ }^{24}$ Observasi, 16/O/F-2/04-VII/2009

${ }^{25}$ Wawancara, 06/1-W/F-1/08-VII/2009

32 Madrasah, Vol. 3 No. 1 Juli-Desember 2011 
Athok Fu'adi - Implementasi Pembelajaran Aktif, Kreatif, Efektif

tidak selalu formal, tetapi bisa saja penilaian dilakukan dalam lingkungan sekolah dan juga dalam lingkungan luar sekolah, dengan sistem observasi. Ada beberapa ranah yang dinilai, yaitu:

\section{a. Penilaian Ranah Kognitif}

Penilaian ranah kognitif merupakan penilaian yang berdasarkan pengetahuan dengan mengedepankan pada aspek intelektual dalam pembelajaran. Bentuk penilaian kognitif dapat berupa ulangan blok, ulangan harian dan berupa tes formatif dan tes sumatif. Tes formatif berlangsung sepanjang semester untuk mengetahui tingkat keberhasilan proses belajar mengajar. Ulangan blok untuk beberapa materi pelajaran yang sudah selesai dipelajari siswa dan diberikan ulangan. Materi tes didasarkan pada tujuan pembelajaran pada tiap-tiap materi.

b. Penilaian Ranah Psikomotor

Penilaian ranah psikomotor merupakan penilaian yang dilakukan untuk mengetahui kemampuan motorik pada diri siswa dengan melihat kinerja yang telah dikuasai siswa yang berkaitan dengan gerak badan. Untuk mencapai kompetensi pada materi-materi psikomotor, guru mengadakan pengalaman belajar berupa praktek menirukan, permainan, gerakan-gerakan. Alat yang digunakan guru dalam penilaian psikomotor adalah data cek list yang sudah tersedia dalam rancangan penilaian.

\section{c. Penilaian Ranah Afektif}

Penilaian ranah afektif digunakan untuk mengukur pencapaian kompetensi yang meliputi antara lain tingkat pemberian respon atau tanggapan, yaitu perasaan, emosi, sistem, nilai dan sikap hati yang menunjukkan penerimaan atau penolakan terhadap sesuatu.

Penilaian afektif juga digunakan guru dalam mengukur minat siswa dalam mengikuti pelajaran. Minat siswa sangat berpengaruh terhadap keberhasilan proses pembelajaran. Untuk mendapatkan nilai afektif, guru melakukan pengamatan dan pencatatan secara harian terhadap perilaku siswa di dalam, tetapi belum menyentuh perilaku yang di luar kelas.

4. Faktor Penghambat Pelaksanaan Pembelajaran PAKEM

Faktor penghambat dalam pembelajaran PAKEM dapat di lihat dari beberapa hal sebagai berikut: 


\section{a. Faktor Guru}

Guru dalam hal ini bersedia atau tidak mengadakan perubahan dalam proses pembelajaran konvensional menuju pembelajaran PAKEM? Karena hasil wawancara ${ }^{26}$ mengatakan kesibukan guru, dan banyaknya media yang disiapkan akan mempengaruhi proses pembelajaran PAKEM yang dilakukannya. Kurangnya persiapan dalam perencanaan pembelajaran, menyebabkan guru kurang siap dalam pembelajaran di kelas. Kedisiplinan guru menjadi dasar dalam kesuksesan guru di kelas.

b. Sarana Prasarana

Kurangnya sarana media disekitar dan kreatifitas guru mempengaruhi dalam pembelajaran PAKEM yang diterapkan, sehingga ini menghambat guru dalam proses pembelajaran.

\section{Analisis Hasil Penelitian Pembelajaran PAKEM}

1. Persiapan Pembelajaran PAKEM

Sebelum pembelajaran berlangsung guru membuat RPP, Prota, Promes dan itu dibuat oleh guru mata pelajaran dan dijilid selanjutnya di tanda tangani kepala sekolah. Semua guru wajib membuat RPP yang berisikan rencana pembelajaran, sehingga dalam pelaksanaan pembelajaran dapat dilakukan dengan baik, sebagaimana di atur dalam Peraturan Pemerintah tahun 2005 pasal 20 bahwa guru sebelum melakukan pembelajaran harus membuat perencanaan. Perencanaan proses pembelajaran meliputi silabus dan rencana pelaksanaan pembelajaran yang memuat sekurang-kurangnya tujuan pembelajaran, materi ajar, metode pengajaran, sumber belajar, dan penilaian hasil belajar

Sesuai dengan Permendiknas Nomor 41 Tahun 2007 tentang Standar Proses dijelaskan bahwa RPP dijabarkan dari silabus untuk mengarahkan kegiatan belajar peserta didik dalam upaya mencapai KD. Setiap guru pada satuan pendidikan berkewajiban menyusun RPP secara lengkap dan sistematis agar pembelajaran berlangsung secara aktif, kreatif, efektif dan menyenangkan (PAKEM), dan dapat menumbuhkan prakarsa, kreativitas, dan kemandirian sesuai dengan bakat, minat, dan perkembangan fisik serta psikologis peserta didik.

${ }^{26}$ Wawancara, 07/1-W/F-1/18-VII/2009

34 Madrasah, Vol. 3 No. 1 Juli-Desember 2011 
Ada beberapa prinsip dalam menyusun RPP:

a. Memperhatikan perbedaan individu peserta didik RPP disusun dengan memperhatikan perbedaan jenis kelamin, kemampuan awal, tingkat intelektual, minat, motivasi belajar, bakat, potensi, kemampuan sosial, emosi, gaya belajar, kebutuhan khusus, kecepatan belajar, latar belakang budaya, norma, nilai, dan/atau lingkungan peserta didik.

b. Mendorong partisipasi aktif peserta didik

Proses pembelajaran dirancang dengan berpusat pada peserta didik untuk mendorong motivasi, minat, kreativitas, inisiatif, inspirasi, kemandirian, dan semangat belajar.

c. Mengembangkan budaya membaca dan menulis

Proses pembelajaran dirancang untuk mengembangkan kegemaran membaca, pemahaman beragam bacaan, dan berekspresi dalam berbagai bentuk tulisan.

d. Memberikan umpan balik dan tindak lanjut RPP memuat rancangan program pemberian umpan balik positif, penguatan, pengayaan, dan remedi.

e. Keterkaitan dan keterpaduan

RPP disusun dengan memperhatikan keterkaitan dan keterpaduan antara SK, KD, materi pembelajaran, kegiatan pembelajaran, indikator pencapaian kompetensi, penilaian, dan sumber belajar dalam satu keutuhan pengalaman belajar. RPP disusun dengan mengakomodasikan pembelajaran tematik, keterpaduan lintas mata pelajaran, lintas aspek belajar, dan keragaman budaya.

f. Menerapkan teknologi informasi dan komunikasi RPP disusun dengan mempertimbangkan penerapan teknologi informasi dan komunikasi secara terintegrasi, sistematis, dan efektif sesuai dengan situasi dan kondisi.

2. Pelaksanaan Pembelajaran PAKEM

Pelaksanaan pembelajaran PAKEM di lembaga MI Ma'arif Polorejo dan MI Ma'arif Setono masih baru, setelah adanya kerjasama dengan PGMI STAIN Ponorogo dan LAPIS PGMI, oleh karena itu perlu dilihat perubahan tersebut;

a. Guru Menggunakan Multimetode 
Tahapan pembelajaran yang sudah dikenal dan dilaksanakan oleh guru-guru dalam kegiatan pembelajaran adalah kegiatan awal, kegiatan inti dan kegiatan penutup. Dalam satu satuan proses pembelajaran ketiga kegiatan mengajar atau ketiga tahap pembelajaran di atas, masing-masing mempunyai peranan penting dalam keseluruhan proses pembelajaran, yaitu: (1) mempunyai sumbangan yang berarti untuk tercapainya tujuan pengajaran, (2) memberikan sumbangan untuk mengefektifkan kegiatan pembelajaran pada tahap yang lain. Maka dari itu, semua tahap pembelajaran (kegiatan awal, kegiatan inti dan penutup) perlu dikelola dengan baik.

Kegiatan pembelajaran akan terselenggara dengan PAKEM apabila guru mampu memilih kegiatan dan metode yang cocok untuk setiap tahap pembelajaran, mulai dari kegiatan awal, kegiatan inti, dan kegiatan penutup. Banyaknya metode yang dipakai untuk pembelajaran PAKEM akan menambah variasi pembelajaran.

Beberapa bentuk kegiatan dan metode yang cocok dilakukan pada kegiatan awal pembelajaran;

1) Mencermati gambar

2) Mencermati video

3) Mencermati kasus

4) Mencermati model atau demonstrasi

5) Mencermati aplikasi konsep dalam kehidupan/teknologi

6) Curah pendapat

7) Kartu pendapat

8) Demonstrasi

9) Tanya jawab

10) Kerja individual

11) Kerja berpasangan

Beberapa bentuk kegiatan dan metode yang cocok dilakukan pada kegiatan inti pembelajaran;

1) Penyelidikan

2) Membaca sumber-sumber otentik

3) Menyelesaikan masalah

4) Membangun model

5) Menganalisis data

6) Berlatih

7) Bertanya jawab

36 Madrasah, Vol. 3 No. 1 Juli-Desember 2011 
Athok Fu'adi - Implementasi Pembelajaran Aktif, Kreatif, Efektif

8) Mendorong siswa untuk bekerjasama tanpa instruksi langsung dari guru

9) Mengamati dan mendengarkan siswa ketika mereka berinteraksi

10) Mempertanyakan arah kegiatan siswa jika diperlukan

11) Menentukan waktu kepada siswa untuk mengikuti seluruh permasalahan

12) Mendorong siswa untuk menjelaskan konsep-konsep dan mendefinisikannya dengan kata-kata mereka sendiri

13) Menanyakan justifikasi (kejadian) dan klarifikasi dari siswa

14) Secara formal menentukan definisi, penjelasan,dan label-label baru

15) Menggunakan pengalaman siswa sebelumnya sebagai dasar untuk menjelaskan konsep-konsep

16) Mendorong siswa untuk mengaplikasikan atau memperluas konsep dan ketrampilan dalam situasi baru.

17) Mengingatkan siswa tentang penjelasan alternatif .

18) Menunjukkan pada siswa data dan kejadian yang ada dan bertanya. Apakah kamu sudah mengerti? Mengapa kamu berfikir demikian?

Beberapa bentuk kegiatan dan metode yang cocok dilakukan pada kegiatan penutup pembelajaran:

1) Refleksi

2) Memberikan masukan jurnal

3) Membangun rubrik

4) Tes kinerja

5) Menghasilkan karya

6) Menilai pengetahuan dan ketrampilan siswa

7) Mencari kejadian yang menunjukkan bahwa siswa telah mengalami perubahan berfikir dan tingkah laku

8) Memberi kesempatan siswa untuk menilai pembelajarannya sendiri dan ketrampilan berkelompok

Di bawah ini adalah beberapa kegiatan yang dapat digunakan dalam pembelajaran yang aktif:

1) Think, pair and share : ajukan permasalahan pada siswa. Berikan kesempatan 2-5 menit untuk berfikir sendiri (think). Setelah selesai mintalah mereka mendiskusikan masalah yang sama dengan siswa disebelahnya selama 3-5 menit (pair). Akhirnya pilihlah satu pasangan untuk mengemukakan pendapat mereka di depan kelas (share).

37 Madrasah, Vol. 3 No. 1 Juli-Desember 2011 
Athok Fu'adi - Implementasi Pembelajaran Aktif, Kreatif, Efektif

2) Kelompok belajar kolaboratif : siswa dibentuk dalam kelompok heterogen 3-6 orang. Mintalah salah satu siswa menjadi pemimpinnya dan satu yang lain menjadi pencatat. Berikan kesempatan pada siswa untuk belajar secara berkolaborasi. Hasil kelompok berupa laporan tertulis.

3) Review bahan : pada separuh waktu yang tersedia siswa diminta untuk bekerja dalam kelompok mereview bahan dengan cara setiap orang mengajukan hal-hal yang belum dipahami dan mendiskusikannya dalam kelompok. Pada separuh waktu berikutnya kelompok-kelompok mengajukan permasalahan dan membantu kelompok yang lain.

4) Pesta Pertanyaan : siswa diminta membaca topik atau materi tertentu. Masing-masing siswa menyiapkan beberapa pertanyaan penting beserta kemungkinan jawabannya. Secara bergiliran siswa menyampaikan pertanyaan dan dibahas bersama teman-temannya serta dikuatkan oleh guru.

5) Debat : kegiatan ini dapat dilakukan baik individual maupun kelompok. Siswa diminta untuk mengajukan pendapat dengan terlebih dahulu mengumpulkan data, fakta dan konsep.

6) Analisa studi kasus : kepada siswa diberikan kasus yang harus dipecahkan baik secara individual maupun secara berkelompok berdasarkan data, fakta atau konsep yang telah dipelajari di kelas.

7) Mengevaluasi hasil kerja teman : dapat dilakukan setelah mengembangkan suatu produk. Umumnya siswa menggunakan rubrik untuk mengevaluasi hasil kerja temannya

8) Bermain peran : masing-masing kelompok diminta merancang permainan peran berdasarkan konsep yang sedang dipelajari. Kelompok yang satu menanggapi hasil permainan peran kelompok yang lain.

9) Membangun model : sama dengan bermain peran masing-masing kelompok diminta untuk mengembangkan model berdasarkan konsep yang dipelajari. Masing-masing kelompok diberi kesempatan untuk mempresentasikan hasil dan ditanggapi kelompok lainnya.

10) Diskusi Panel : siswa diminta menyiapkan presentasi untuk dipanelkan di depan kelas. Panelis memaparkan presentasinya dan diikuti dengan memberikan kesempatan pada audien untuk bertanya. 
Athok Fu'adi - Implementasi Pembelajaran Aktif, Kreatif, Efektif

Macam-macam kegiatan untuk mengetahui penguasaan siswa terhadap konsep yang telah dipelajari:

1) Menulis Newsletter : dalam kelompok kecil siswa menyusun newsletter berupa artikel pendek yang terkait dengan konsep yang sedang dipelajari.

2) Mengembangkan peta konsep : secara individual ataupun kelompok siswa diminta untuk mengembangkan peta konsep yang merupakan representasi gagasan, model, konsep atau hubungan antar konsep. Siswa membuat bulatan-bulatan yang didalamnya terdapat konsep dan garis yang menghubungkan antara bulatan yang satu dengan yang lainnya.

3) One minute paper : kegiatan ini dapat dilakukan di akhir pembelajaran. Mintalah siswa mengeluarkan secarik kertas. Ajukan sebuah pertanyaan terbuka atau tertutup terkait konsep yang telah dipelajari. Berikan waktu satu atau dua menit bagi siswa untuk menjawabnya.

4) Yang jelas dan yang masih ragu : hampir mirip dengan one minute paper, mintalah siswa menuliskan hal-hal yang telah jelas dan yang masih meragukan atau bahkan yang mereka belum paham sama sekali. Hal ini sangat penting untuk mereview konsep pada pertemuan berikutnya.

5) Refleksi : mintalah satu atau dua siswa maju di depan kelas dan menceritakan kesan terhadap pembelajaran. Refleksi juga dapat memancing perasaan dan kesulitan siswa dalam mengikuti pembelajaran.

6) Quis : guru mengajukan beberapa masalah atau soal terkait konsep dan meminta siswa menjawabnya. Quis dapat dilakukan dengan menyertakan nama siswa maupun tidak mencantumkan nama.

7) Simulasi/latihan praktek : setelah siswa belajar tentang keterampilan motorik tertentu, secara acak siswa diminta untuk mempraktekkan keterampilan yang telah dipelajari di depan kelas.

8) Turnamen : secara berkelompok siswa berkompetisi untuk menyelesaikan masalah yang terkait dengan konsep yang telah dipelajari. Kelompok siswa yang memenangkan turnamen mendapatkan reward tertentu.

b. Guru Menggunakan Media Pembelajaran 
Penyelenggaraan PAKEM tidak terlepas dari kreativitas guru dalam pemanfaatan sumber belajar yang sesuai dengan kegiatan pembelajaran yang dilaksanakan. Guru yang sudah mampu menyelenggarakan PAKEM dengan baik, selalu memiliki keterampilan memanfaatkan sumber belajar yang ada dengan baik sehingga pembelajaran yang dilaksanakan bisa berjalan secara baik. Ada dua macam sumber belajar, yaitu sumber belajar yang dirancang dan sumber belajar yang dimanfaatkan.

Sumber belajar yang dirancang contohnya: buku teks, buku paket, foto-slide pembelajaran, video pendidikan, laboratorium Sains dan Bahasa, alat peraga edukatif, dll. Sumber belajar yang dimanfaatkan contohnya: pasar, toko, museum, kantor pos, tempat ibadah, posyandu, tugu peringatan, rumah sakit, taman, nara sumber, sungai, sawah, balai desa, kantor kecamatan, pabrik, puskesmas, dll.

\section{c. Guru Mengelola Kelas dengan Dinamis}

Komponen lain yang mempengaruhi penyelenggaraan PAKEM adalah pengelolaan kelas. Pengelolaan kelas yang kondusif untuk penyelenggaraan PAKEM harus diciptakan supaya PAKEM yang direncanakan dapat diterapkan dengan baik. Pengelolaan kelas dapat dikategorikan menjadi pengelolaan kelas yang sifatnya fisik dan pengelolaan kelas yang sifatnya non fisik.

1). Pengelolaan kelas Fisik

a) Pengelolaan tempat duduk (bangku)

b) Pengelolaan pajangan kelas

c) Pengelolaan alat peraga

d) Pengelolaan sudut baca/perpustakaan kelas

e) Pengelolaan alat bantu belajar

2). Pengelolaan kelas non fisik

a) Menjalin hubungan baik dengan siswa

b) Menyeimbangkan pujian dan kritik

c) Menciptakan disiplin kelas

Ruangan kelas, posisi kursi dan meja serta meja guru perlu ditata untuk menunjang kegiatan belajar mengajar yang mengaktifkan siswa. Dilihat dari beberapa observasi, lingkungan kelas kurang begitu mendukung sebab banyaknya meja kursi melebihi kapasitas ruangan. Ruangan kelas kelihatan penuh dengan kursi sehingga ruang gerak siswa dan guru terbatasi. Tetapi kondisi fisik seperti itu tidak mempengaruhi 
proses pembelajaran di kelas karena siswa masih bisa menjangkau alat-alat pembelajaran dengan lewat jalan yang ditata diantara kursi dan meja.

Model pengelolaan kelas yang baik mendorong terciptanya suasana yang kondusif dan memberikan motivasi untuk belajar, sehingga siswa tidak merasa lelah dan jenuh. karena dalam mengajar guru telah menerapkan pembelajaran aktif ${ }^{27}$. Pengondisian kelas, masing-masing guru berbeda kemampuannya, tergantung bagaimana guru berinteraksi di dalam kelas. Interaksi yang baik dapat menunjang keberhasilan siswa dalam menguasai materi. Pengelolaan interaksi yang dimaksud adalah bagaimana guru mengatur situasi dan kondisi awal, serta bagaimana mengendalikan kelas agar pembelajaran berlangsung efektif.

\section{d. Guru Menampilkan Pajangan Karya Siswa}

Kelas yang memiliki pajangan akan dapat mendukung proses pelaksanaan PAKEM. Adapun pajangan kelas dikelola dengan memperhatikan beberapa hal berikut:

1) Pajangan dipasang pada tempat yang mudah dibaca oleh anak (tidak terlalu tinggi)

2) Pekerjaan anak hendaknya dipajangkan secara individual sehingga dapat dikenali dengan mudah; tidak bercampur dengan yang lain, atau tidak dalam bendelan.

3) Yang dipajangkan hendaknya dalam keadaan bersih, rapi dan menarik.

4) Materi yang dipajangkan dapat ditempelkan pada dinding, digantungkan pada langit-langit ruangan, digantungkan pada tali/kawat yang dibentangkan dari dinding samping kanan ke dinding samping kiri kelas atau diatur pada meja pamer.

5) Pajangan diganti apabila sudah tidak menarik lagi atau menjadi kotor

Materi yang dapat dipajangkan berupa Hasil karya siswa;

a) Tulisan anak seperti cerita, karangan, puisi, laporan, buku yang dibuat oleh anak, model, grafik, gambar dan hasil kerajinan atau kesenian.

b) Hasil pekerjaan anak yang menunjukkan ada unsur kreatifitas dan menarik untuk dilihat dan dibaca hendaknya dipajangkan.

c) Contoh-contoh hasil karya anak yang baik untuk dipajangkan

d) Kadang-kadang hasil kerja anak yang lambat (slow learner) perlu dipajangkan untuk memotivasi mereka

\footnotetext{
${ }^{27}$ Lihat transkrip wawancara no: 01/W/F-1/12-VII/2008 dalam lampiran ini
} 
Materi yang dapat dipajangkan berupa bahan cetak;

a) Gambar, chart, diagram dan benda-benda yang relevan dengan kegiatan yang sedang dibahas di kelas.

b) Buku untuk anak yang harus dibaca dan dilihat

c) Bahan, sumber belajar dan peralatan yang sedang digunakan untuk kegiatan belajar.

e. Setiap Kelas Ada pojok Baca

Kelas perlu menyediakan banyak sumber belajar, seperti buku, majalah, koran dan sebagainya baik baru maupun bekas (lama). Guru dan siswa dapat mengumpulkan sumber belajar ini dengan berbagai cara, seperti siswa membawa buku, majalah dan sebagainya yang sudah tidak dipergunakan, meminta pada paguyban kelas atau masyarakat untuk menyumbangkan buku, majalah atau koran dan sebagainya. Untuk merangsang siswa membaca buku, kegiatan seperti membaca dalam hati selama 10 menit sebelum kelas di mulai di pagi hari, meminta siswa menceritakan kembali isi bacaan dan sebagainya perlu digalakkan. Perlu juga dibuat aturan pemakaian dan pengembalian buku ke tempat semula setelah memakainya.

\section{f. Setiap Kelas ada Alat Peraga}

Agar pelaksanaan PAKEM berjalan lancar, kelas perlu memiliki alat peraga yang memadai. Alat peraga tidak harus dibeli tetapi dapat dibuat dari bahan-bahan sederhana. Guru dan siswa dapat bekerja bersama untuk membuat alat peraga.

Beberapa hal yang terkait dengan pengelolaan alat peraga diantaranya adalah sebagai berikut;

1) Berusaha untuk membuat alat peraga sebanyak mungkin terutama untuk hal-hal yang abstrak. Alat peraga dapat dibuat dari bahan bekas atau sederhana

2) Alat peraga diletakkan pada tempat yang mudah dijangkau siswa tetapi tetap aman

3) Alat peraga diupayakan sering digunakan, disamping untuk meningkatkan kualitas pembelajaran juga meningkatkan apresiasi siswa terhadap alat peraga.

4) Aturan penggunaan alat peraga perlu dibuat dan ditaati 


\section{Penilaian Pembelajaran PAKEM}

Penilaian merupakan suatu proses pengumpulan, pelaporan dan penggunaan informasi tentang hasil belajar siswa yang diperoleh melalui pengukuran untuk menganalisa atau menjelaskan unjuk kerja atau prestasi siswa dalam mengerjakan tugas-tugas. PBK merupakan proses hasil pembelajaran. Penilaian tidak selalu formal, tetapi bisa saja penilaian dilakukan dalam lingkungan sekolah dan juga dalam lingkungan luar sekolah, dengan sistem pengamatan. Dalam mengadakan penilaian guru menggunakan pengamatan tes dan alat. Nilai yang diperoleh dari hasil pengamatan guru dicatat dalam buku catatan. Di dalam buku catatan harian tersebut tertulis nilai-nilai siswa yang meliputi ranah afektif, kognitif dan psikomotor.

Tagihan-tagihan tersebut digunakan untuk mengetahui pengusaan pada ranah kognitif, ranah afektif dan psikomotor.

\section{a. Penilaian Ranah Kognitif}

Penilaian ranah kognitif merupakan penilaian yang berdasarkan pengetahuan dengan mengedepankan pada aspek intelektual dalam pembelajaran. Bentuk penilaian kognitif dapat berupa ulangan blok, ulangan harian dan berupa tes formatif dan tes sumatif. Tes formatif berlangsung sepanjang semester untuk mengetahui tingkat keberhasilan proses belajar mengajar. Ulangan blok untuk beberapa materi pelajaran yang sudah selesai dipelajari siswa dan diberikan ulangan. Materi tes didasarkan pada tujuan pembelajaran pada tiap-tiap materi.

Penilaian kognitif dalam tes formatif yang ada dalam rancangan penilaian dapat berupa:

1). Tes tulis, yaitu dengan mengerjakan tes tulis dari guru berupa menjawab soal-soal dari pilihan ganda

2). Tes lisan, yaitu pertanyaan-pertanyaan yang diajukan guru secara lisan untuk mengetahui tingkat penyerapan materi yang telah selesai dibahas. Dalam hal ini ketika materi warisan, guru memberikan pertanyaan-pertanyaan tentang bagaiamana menghitung harta warisan, dan beliau memberikan nilai pada pertanyaan-pertanyaan tersebut pada siswa yang menjawab, guru tidak hanya menilai bagaimana siswa menjawab tetapi menilai juga respon atau inisiatif yang muncul dari siswa misalnya siapa yang lebih dulu menjawab atau siapa yang mampu maju untuk menghapal pelajaran yang 
disampaikan oleh guru. Jadi, penilaian ini menyentuh ranah kognitif dan psikomotor.

3). Ulangan harian, yaitu ulangan yang dilaksanakan secara berkala setiap selesai satu materi tertentu. Bentuk soal ulangan harian antara lain: uraian non objektif, pilihan ganda.

4). Tugas individu atau kelompok, yaitu tugas yang diperintahkan siswa untuk menambah penilaian yang bersifat tugas dengan individu dan kelompok dipresentasikan ke depan kelas.

Tugas kelompok biasanya diberikan untuk materi yang membutuhkan waktu agak lama dalam pengerjaannya. Tujuan dari tugas kelompok tidak hanya untuk mempercepat penyelesaian tugas dari guru tetapi juga tujuan melatih kebersamaan dan kerjasama.

\section{b. Penilaian Ranah Psikomotor}

Penilaian ranah psikomotor merupakan penilaian yang dilakukan untuk mengetahui kemampuan motorik pada diri siswa dengan melihat kinerja yang telah dikuasai siswa yang berkaitan dengan gerak badan dalam pembelajaran. Untuk mencapai kompetensi pada materi-materi psikomotor guru mengadakan pengalaman belajar berupa praktek menirukan, permainan, gerakan-gerakan yang dikuasai.

\section{c. Penilaian Ranah Afektif}

Penilaian ranah afektif digunakan untuk mengukur pencapaian kompetensi yang meliputi antara lain tingkat pemberian respon atau tanggapan, yaitu perasaan, emosi, sistem, nilai dan sikap hati yang menunjukkan penerimaan atau penolakan terhadap sesuatu.

\section{E. Kesimpulan}

1. Persiapan pembelajaran PAKEM, ditemukan beberapa guru belum membuat RPP yang sesuai dengan ciri PAKEM, hal ini dikarenakan masih terpaku pada model pembelajaran sebelumnya.

2. Pelaksanaan pembelajaran PAKEM, pelaksanaan pembelajaran sudah berjalan tetapi belum sepenuhnya dilakukan oleh semua kelas, hanya beberapa kelas.

3. Pelaksanaan penilaian, untuk penilaian berbasis kelas dan menggunakan 3 ranah, kognitif, afektif dan psikomotorik, tetapi untuk menerapkan semua itu kesulitan. 
Athok Fu'adi - Implementasi Pembelajaran Aktif, Kreatif, Efektif

4. Hambatan dan dukungan dalam pembelajaran PAKEM, hambatan terletak pada guru itu sendiri dan sarana prasarana berupa media pembelajaran, sedangkan dukungan dari semua stakeholder.

\section{F. Daftar Rujukan}

Block, James H. (1971). Mastery learning: Theory and practice. New York: Holt, Rinehart and Winston, Inc.

Daradjat, Zakiah. (1993). Psikologi Agama, Jakarta: Bulan Bintang

Depdiknas. (2002). Kurikulum berbasis kompetensi. Jakarta: Puskur, Balitbang Depdiknas

Gunarso, S.D. (1985). Dasar dan perkembangan anak. Jakarta: PT. Gunung Mulia

Gordon, Thomas. (1986). Guru yang efektif: Cara untuk mengatasi kesulitan dalam kelas. (penyadur: Mudjito). Jakarta: Rajawali.

Hurlock, Elizabets. (1978). Perkembangan anak. Jakarta: Gelora aksara pratama

Hurloch, Elizabeth. (1980). Developmental Psychology.New York: Mc. Graw Hill. Inc

Hurlock, Elizabeth B. (1996). Psikologi Perkembangan, Jakarta: Erlangga . (1991). Perkembangan Anak Jilid 1, Jakarta: Erlangga (1991). Perkembangan Anak Jilid 2, Jakarta: Erlangga

Hilgard, E.R., \& Bower, G.H. (1975). Theory of learning (5nd ed). Englewood Cliffs, NJ: Prentice-Hall.

Inggridwati Kurnia. (2007). Perkembangan Peserta Didik, Jakarta: Depdiknas

Miles, M.B., \& Huberman, A.M. (1992). Analisis data kualitatif. (Terjemahan Tjetjep Rohendi Rohidi. Jakarta: Universitas Indonesia (UI-Press).

Muhadjir, Noeng. (1987). Ilmu pendidikan dan perubahan sosial, suatu teori pendidikan. Yogyakarta: Rake Sarasin.

Mukminan. (2003). Pembelajaran tuntas (mastery learning). Jakarta: Direktorat Lanjutan Pertama.

45 Madrasah, Vol. 3 No. 1 Juli-Desember 2011 
Athok Fu'adi - Implementasi Pembelajaran Aktif, Kreatif, Efektif

Suyanto \& Abbas. (2001). Wajah dan dinamika pendidikan anak bangsa. Yogyakarta: Adicita Karya Nusa.

S. Muhibbin. (1999). Psikologi Belajar, Ciputat: Logos Wacana Ilmu

Sukmadinata. 92003). Landasan Psikologi Proses Pendidikan, Bandung: Rosdakarya

Sumantri, Mulyani, dan Nana Syaodih. (2007). Perkembangan Peserta Didik. Cet.XVII. Jakarta: Universitas Terbuka

Syamsu Yusuf LN. (2006). Psikologi Perkembangan Anak dan Remaja. Cet.VII. Bandung: Remaja Rosdakarya

Undang-undang Republik Indonesia No 20 Tahun 2003 tentang UndangUndang Sistem Pendidikan Nasional. Bandung : Citra Umbara.

Usman, Uzer. (1992). Menjadi guru profesional. Bandung: Remaja Rosdakarya.

Woolfolk, A.E. \& Lorraine. M.N. (1984). Educational psychology for teachers. Englewood Cliffs, NJ: Prentice-Hall, Inc

Yusuf Syamsu L.N. (2007). Buku Materi Pokok Pedagogik Pendidikan Dasar. Bandung: Sekolah Pascasarjana Universitas Pendidikan Indonesia.

Zamroni. (2000). Paradigma pendidikan masa depan. Yogyakarta: BIGRAF Publising. 